\title{
IN DEFENCE OF SUBSTANTIAL SENTENCING DISCRETION
}

\begin{abstract}
This article develops an ideal of sentencing discretion as consisting in sufficient dispositional flexibility for the trial judge to set, on behalf of the polity, reasonable terms for the continuance of relations with the offender in view of his crime. This ideal requires trial judges to have what may be termed "substantial" sentencing discretion: discretion that is exercised with direct reference to the values and goals penal sanctions are expected to serve, and where it is this quality of valuebased engagement that provides the justification for the decision. The article engages with empirical research into sentencing that helps us address the strength of the case for and against substantial sentencing discretion, and ultimately defends substantial sentencing discretion on functional as well as ethical-political grounds.
\end{abstract}

Judicial discomfort with wide sentencing discretion is not unknown, nor is it a thing of the past. Judge Marvin Frankel's broadside against the extent of sentencing discretion possessed by him and his brethren in the 1970s, charging "lawlessness in sentencing", is a matter of historical record. ${ }^{1}$ In a fairly recent Canadian Court of Appeal judgment, we read that:

* University Senior Lecturer, Faculty of Law, Deputy Director, Centre for Penal Theory and Penal Ethics, Institute of Criminology, University of Cambridge. E-mail: alp22@cam.ac.uk

${ }^{1}$ M E Frankel, "Lawlessness in Sentencing", (1972) 41 University of Cincinnati Law Review 1. Frankel also published an extended version as a book: M E Frankel, Criminal Sentences: Law without Order, New York: Hill \& Wang, 1972. Equally matters of historical record are the multifaceted subsequent attempts to verify the charge, and to develop presumptive remedies which have, in turn, become highly contentious: see e.g. A Blumstein et al (eds), Research on Sentencing: The Search for Reform, vols 1 and 2, Washington, DC: National Academy Press, 1983; M Tonry, Sentencing Matters, Oxford: Oxford University Press, 1996; C Spohn, How Do Judges Decide? The Search for Fairness and Justice in Punishment, 2nd edn, Thousand Oaks: Sage, 2009. 
it is notorious among judges ... that one of the most controversial subjects, both in theory and practical application is sentencing. ... The proposition that if judges knew the facts of a given case, they would all agree, or substantially agree on the result, is simply not so. ... Without reasonable uniformity of approach to sentencing amongst trial and appellate judges ..., many of the sentencing objectives and principles prescribed in the Code are not attainable. ... This makes the search for just sanctions at best a lottery and at worst a myth. Pretending otherwise obscures the need for [the] courts to ... minimize unjustified disparity in sentencing while maintaining flexibility. ${ }^{2}$

Of course, no modern legal system leaves entirely unconstrained sentencing powers to trial judges. There is a general division of labour between the legislature and the courts, where the outer boundaries of a court's sentencing powers are set by the punishment types and ranges authorised for certain kinds of offences in the criminal code, and where the code may also contain a statement of the aims of sentencing, and/or lists of aggravating and mitigating factors to be taken into account in the determination of sentence. ${ }^{3}$ There is also a degree of internal institutional control of sentencing outcomes through appellate review. In such a system, the sentencing decision is thus anchored by legislatively authorised penalty ranges, and in principle subject to corrective adjustment within the judicial branch of government. Last but not least, there are often constitutional principles that curtail the penal power of the state vis-à-vis those under its jurisdiction, for instance by prohibiting cruel and unusual, or disproportionate, punishment.

The question addressed in this article is what type of sentencing discretion a system of this kind should embrace. What efforts, if any, should be made to ensure that offenders whose criminal behaviour was of comparable gravity are sentenced to essentially identical punishments? And what should judges focus on in reaching their decisions - a pre-determined set of classificatory criteria from which a certain punishment will follow in all cases of this kind, or specific goals of punishment? In practice, the answers to these questions will, in part, depend on further legal determinations made by the criminal justice system in question. But what can be said in general terms about the proper extent of sentencing discretion in a legal system

\footnotetext{
${ }^{2}$ R. v. Arcand, [2010] A.J. No. 1383, 264 C.C.C. (3d) 134 (Alta.C.A.), para. 8.

${ }^{3}$ Despite the existence of common law crimes this is now also largely true for a common law system, such as England and Wales, where offences created by legislation now far outnumber common law crimes, some common law crimes (such as murder) are subject to legislatively defined punishments, and general sentencing legislation also applies to sentencing for common law crimes.
} 
committed to the control of state power, respect for fundamental rights and equality before the law?

This article defends a trial judge's sentencing discretion on practical as well as ethical-political grounds. It develops an ideal of sentencing discretion as consisting in sufficient dispositional flexibility for the trial judge to ensure that what he considers to be the most appropriate penal sanction is imposed on a convicted offender. The appropriateness of the sanction is judged in terms of the overall task and objective of the criminal justice process to set, on behalf of the polity, reasonable terms for the continuance of relations with the offender in view of his crime. This ideal requires trial judges to have what may be termed "substantial" sentencing discretion: discretion that is exercised with direct reference to the values and goals penal sanctions are expected to serve, and where it is this quality of valuebased engagement that provides the justification for the decision. The exercise of substantial sentencing discretion has three interrelated features: it requires of the judge to engage with the morally salient features of the case before him, including the question how the punishment will affect the offender in human terms; sentencer and sentenced experience the sentencing occasion as a moral interaction where the judge imposes a sentence for reasons he can give and stand behind; and its exercise preserves a judge's sense of personal moral responsibility for sentence he imposes.

Opponents of the view defended here are unlikely to argue against any degree of sentencing discretion within the criminal justice system. ${ }^{4}$ Rather, they will defend a set of constraints designed to minimise inter-judge disparity in sentencing outcomes. Such constraints will typically (a) define and standardise factors pertaining to case severity, (b) connect particular case severity values to specific penal options within a narrow band, and (c) suppress the possibility that judges, by emphasising different sentencing goals, reach significantly different outcomes in factually comparable cases. ${ }^{5}$ In doing so, such

\footnotetext{
${ }^{4}$ Tata observes that "even the advocates of stricter numerical guidelines and of 'expert systems' have stressed that their work should not be seen as an attempt to appropriate the proper exercise of judicial discretion but rather simply as an 'aid' or way ... to 'structure' the use of discretion in individual cases." C Tata, "Accountability for the Sentencing Decision Process - Towards a New Understanding" in C Tata and N Hutton (eds), Sentencing and Society: International Perspectives, Aldershot: Ashgate, 2002, 399, 401. See also T O'Malley, "Judgment and Calculation in the Selection of Sentence", in this issue, Part I.

${ }^{5}$ These features and aims are emblematic of guideline systems.
} 
further constraints may well compromise or even remove substantial sentencing discretion from trial judges.

The case against substantial sentencing discretion, which is reviewed in the first Part of this article, builds on the right to equal treatment of those subject to the authority of the law. Various scholars, some judges, and numerous politicians have claimed that the exercise of sentencing discretion generates unwarranted disparity in sentencing outcomes; indeed, it is this concern that has driven the development of sentencing guidelines in various jurisdictions. ${ }^{6}$ Taking a closer look at some of the empirical literature that has been relied on to back up this claim, I suggest that the evidence for unwarranted disparity may be weaker than often assumed. The differences found appear to be largely traceable to legitimate sentencing considerations and thus indicative of warranted rather than unwarranted disparity.

The claim that sentencing discretion leads to problematic or unfair sentencing outcomes then mainly comes to rest on the contention that "who sentences you" makes a difference to the kind and severity of the sentence that an individual offender receives, in that "the person of the judge", including his or her personal beliefs, background, and penal preferences, play out in significantly different sentencing decisions for comparable cases. This is indeed supported by a considerable body of empirical research on inter-judge disparity in sentencing outcomes. These findings probably provide the best evidence of the presence of some idiosyncratic variation in sentencing outcomes within the system.

The second Part of the article therefore addresses the question whether we have good reason to suppress this potential source of unwarranted disparity by significantly curtailing the discretion left to sentencers. I first address the arguments traditionally raised against such curtailment: that judges need sufficient flexibility to respond to

\footnotetext{
${ }^{6}$ For the U.S., see e.g. I H Nagel, "Structuring Sentencing Discretion: The New Federal Sentencing Guidelines" (1990) 80 Journal of Criminal Law and Criminology 883. Nagel was a Commissioner of the United States Sentencing Commission. The political history of the Federal sentencing guidelines' introduction is traced in K Stith and J A Cabranes, Fear of Judging: Sentencing Guidelines in the Federal Courts, Chicago: University of Chicago Press, 1998, Ch. 1. For England and Wales, see A Ashworth and J V Roberts, "The Origins and Nature of the Sentencing Guidelines in England and Wales" in A Ashworth and J V Roberts (eds), Sentencing Guidelines: Exploring the English Model, Oxford: Oxford University Press, 2013. On the merits and demerits of different guideline methodologies, see further O'Malley, fn. 4 above, Part II.
} 
the "uniqueness" of the cases before them, that curtailing their discretion is a threat to judicial independence, and that discretion is necessary to allow room for mercy. These do not in my view suffice to show that the proper performance of the sentencing function requires judges to have substantial sentencing discretion in every case.

A stronger case for substantial sentencing discretion begins to emerge when we turn our attention to the penal sentence's distinctive forward-looking function of setting reasonable terms for the polity's continued relationship with the offender in respect of his crime. I draw on empirical research involving interviews with judges, courtroom observations and case file reviews to show that decision-makers who approach sentencing as a directly value-oriented decision tend to seek, and often reach, moderate sentencing outcomes. Two factors seem to be at work: First, such an approach heightens attention to offender-oriented considerations at sentencing. Second, it affects the decision-maker's attitude to her decision. Judges' descriptions of their sentencing experiences strongly suggest that when sentencing requires direct engagement with the public values and human interests including those of the offender - at stake in the decision, then (notwithstanding the fact that the sentencing decision is legally guided and restrained, and constitutes an exercise of authority on behalf of the state) the decision-maker experiences it as a moral decision on her part and has an acute sense of moral responsibility for the sentence imposed. This decision-making context, moreover, means that both sentencer and sentenced experience the sentencing occasion as a moral interaction. In the convicted person this furthers a sense that his own humanity is recognised and respected and that his human interests have not counted for nothing in the selection of sentence. In the sentencer it promotes humility and a search for constructive punishments.

This is not, of course, to claim that a system which invests judges with substantial sentencing discretion is without risk. In the final subsection of Part II, I address how sentencers should, and shouldn't, have regard to the goals and values underpinning the criminal justice system. In this discussion I connect the exercise of substantial sentencing direction to an ideal of individualised, person-responsive sentencing. The conclusion sets this ideal of sentencing in the broader context of constitutional values.

Before I turn to the substance of my argument, I should point out that I will not as such address the compatibility of substantial sentencing discretion with guideline systems. In practice, this will depend 
on the design of the guidelines. While certain problems and phenomena that have arisen under the U.S. federal sentencing guidelines were - as I suggest in Part II - rooted in these guidelines' removal of substantial discretion from judges, it may be possible to design sentencing guidelines that preserve and are indeed supportive of the exercise of substantial sentencing discretion. This is a topic to be explored on another occasion.

\section{THE CASE AGAINST SUBSTANTIAL SENTENCING DIS- CRETION: DISPARITY RESEARCH REVISITED}

The claim that sentencing discretion generates unwarranted disparity in sentencing outcomes is supported by three interrelated assumptions: First, that comparable cases are sentenced differently by different judges; second, that these differences at least in part reflect individual judges' differing penal-philosophical outlooks and/or unconsidered biases and personal attitudes; and third, that it is on account of inadequate constraints on sentencing that such differences persist. Defenders of sentencing discretion, by contrast, usually insist that sentencing, to be defensible, must be an individualised process which would be inappropriately constrained by legal instruments that prevent appropriate individualisation of sentences. While some concede a degree of unwarranted outcome disparity but view this as a cost that must be paid to preserve appropriate levels of discretion within the system, others challenge the perception of unwarranted disparity as such and insist that, at the end of the day, judges converge both in approach and in sentencing outcomes, with discrepancies being more apparent than real. Yet others suggest that the best way to overcome unwarranted disparity, and avoid introducing fresh grounds for unfairness through unwarranted uniformity, lies in methods that harness the advantages of structured and self-reflective decision-making while preserving flexibility of outcomes within broadly set boundaries.

My discussion in this Part focuses on studies that compare how judges consciously arrive at their decisions. In doing so I do not mean to deny that (like all human behaviour) judicial decision-making is subject to heuristic shortcuts and affected by subconscious attitudes and biases. My focus falls on studies which address how sentencing decision-making works at a conscious level because this - being the level where deliberative processing of information and application of identifiable legal criteria in the search for appropriate outcomes take 
place - is the level that legal modifications of the sentencing process strive to influence.

\subsection{Research Findings on Sentence Disparity}

Establishing the existence of sentencing disparity as such is not without its methodological difficulties and challenges. ${ }^{7}$ A large number of studies rely on official statistical data on sentencing outcomes for the identification of variations in sentencing patterns. ${ }^{8}$ As many of these studies' authors recognise, one difficulty in drawing from these variations an inference to the unequal sentencing of comparable cases is that it is often unclear how comparable these cases really are. ${ }^{9}$ Most government statistics merely record the disposal of the case by "lead offence" for which an accused has been convicted and sentenced. This does not allow researchers to assume that the cases were of comparable severity, since both regional patterns of criminality and regional prosecution policies may differ and affect what sorts of cases reach the courts to be sentenced. For this reason, disparity research has long tried to probe more deeply than the surface level of outcome statistics, and researchers have employed a range of different methods in their efforts to establish both the existence of unwarranted disparity as such, and its possible causes. ${ }^{10}$ Unwarranted disparity in this context is the occurrence of signifi-

\footnotetext{
${ }^{7}$ For a good discussion of these, see P J Hofer, K R Blackwell and R B Ruback, "The Effect of the Federal Sentencing Guidelines on Inter-Judge Sentencing Disparity", (1999) 90 Journal of Criminal Law and Criminology 239, 264-292.

${ }^{8}$ For the kind of data available in official statistics, see e.g. M Motivans, Federal Justice Statistics, 2013 - Statistical Tables, NCJ 249150, Bureau of Justice Statistics (March 2017); M R Durose, State Court Sentencing of Convicted Felons, 2004 Statistical Tables, NCJ 217995, Bureau of Justice Statistics (1 July 2017). For the kind of analyses that this data makes possible, see W Rhodes et al, Federal Sentencing Disparity: 2005-2012, Bureau of Justice Statistics Working Paper Series, WP2015:01 (22 October 2015) (with a specific focus on how to establish whether racial disparities in sentencing exist).

${ }^{9}$ Palys and Divorski put this succinctly: "[One] is ... left to infer judicial variability in sentencing from unexplained variance ... But sensitivity to the lack of synonymy between 'available' and 'important' data leaves one with a lack of closure, since one cannot determine the extent of which one is actually observing the impact of judicial variability, or merely the absence of important case data." (T S Palys and S Divorski, "Explaining Sentence Disparity", (1986) 28 Canadian Journal of Criminology 347, 348).
}

${ }^{10}$ For a review of recent studies, see J T Ulmer, "Recent Developments and New Directions in Sentencing Research", (2012) 29 Justice Quarterly 1. 
cantly divergent disposals of comparable cases for which no adequate explanation in terms of legitimate sentence grounds can be given. ${ }^{11}$ This adds the complication that such grounds may differ between jurisdictions, or in the same jurisdiction over time, and/or between different classes of offenders. Most sentencing research occurs in respect of offences and classes of offenders where the comparability of cases, in reflection of the legally significant criteria, is established with reference to widely used indicators of the gravity of the offending behaviour (type and degree of harm, levels of culpability, aggravating and mitigating factors pertaining to offending context and motivation). Occasionally, however, studies concern offenders where sentencers are expected to tailor sentences to rehabilitative options and needs. ${ }^{12}$ If the latter is the case, factors that go towards an offender's rehabilitative potential would have to be incorporated into the identification of comparable cases before consistency of disposals can be analysed.

Sometimes it is possible for researchers to base their study on a full review of court files, which allows them to identify and record factors generally accepted as relevant to sentencing outcomes. ${ }^{13}$ These studies are particularly useful in providing nuanced insights into the sentencing patterns of different individuals and courts and are therefore more helpful than bare statistical evaluations in identifying unaccounted-for variations (or in finding that apparent variations can largely be accounted for). A highly popular methodology is vignette-based studies, where judges (and sometimes other judicially trained personnel) are given hypothetical cases to sentence and often asked to give supplementary accounts of the basis for their decision. ${ }^{14}$

${ }^{11}$ The U.S. Panel on Sentencing Research noted, "[Sentencing] disparity exists when 'like cases' with respect to case attributes - regardless of their legitimacy - are sentenced differently" (A Blumstein et al (eds), Research on Sentencing vol. 1, fn. 1 above, 72). See also A Ashworth, "Disentangling Disparity" in D C Pennington and S Lloyd-Bostock (eds), The Psychology of Sentencing: Approaches to Consistency and Disparity, Oxford: Centre for Socio-Legal Studies, 1987, Ch. 3.

${ }^{12}$ For an example of such a study, see A N Doob and L A Beaulieu, "Variation in the exercise of judicial discretion with young offenders", (1992) 34 Canadian Journal of Criminology 35.

${ }^{13}$ For one large study of this kind, see R Hood, Race and Sentencing, Oxford: Clarendon Press, 1992. Hood evaluated the case files of cases relating to 2,884 individuals sentenced in West Midlands Crown Courts in 1989.

${ }^{14}$ For large studies of this kind, see e.g. K Clancy et al, "Sentence Decisionmaking: The Logic of Sentence Decisions and the Extent and Sources of Sentence Disparity", (1981) Journal of Criminal Law and Criminology 524 (conducted with 264 
These studies are particularly good at tracking participants' reasoning processes and at testing whether their generalised and abstract views filter through into the hypothetical case disposals. The hypothetical nature of the exercise is, however, in itself a significant drawback. One can never be quite certain that an actual case which exhibits the features of the hypothetical case would be perceived, and dealt with, in the same way. ${ }^{15}$ Some of the most sophisticated studies are able to combine different methodologies, relying on statistical data, case files, court observation, actual sentencing decisions and additional questionnaires and/or in-depth interviews with the decision-makers concerned. ${ }^{16}$ Many of the in-depth studies, however, are conducted with relatively small numbers of participants, raising different concerns about the generalisability of their findings. Studies of the latter kind are also often not designed to test whether unwarranted outcome disparity exists but to understand how, that is by what mental processes, the sentencing decision is arrived at.

One of the consistent findings of the relatively coarse-grained statistical analyses made possible by official data on the disposals of apparently comparable cases, is that sentencing patterns differ between different courts and regions in ways that cannot plausibly be ascribed to hidden variations in the seriousness of the cases that come before these courts. ${ }^{17}$ Thus, in the 1960s and 1970s various studies

Footnote 14 continued

active U.S. federal district judges); Palys and Divorski, fn. 9 above (conducted with 206 judges of the Canadian provincial courts); F Streng, Strafzumessung und relative Gerechtigkeit. Eine Untersuchung zu rechtlichen, psychologischen und soziologischen Aspekten ungleicher Strafzumessung, Heidelberg: v.Decker, 1984 (conducted with 522 judges, prosecutors and legal trainess in the Lower Saxony region of Germany). For some concerns regarding the external validity of such studies, see $\mathrm{N}$ Lemon and $\mathrm{R}$ Bond, "Some methodological problems in sentencing research", in Pennington and Lloyd-Bostock, fn. 11 above, 46, 50-51.

${ }^{15}$ Partridge and Eldridge, who distributed brief pre-sentence reports to 50 district court judges and observed wide disparity in suggested sentences, call this the "paper defendant" problem (A Partridge and W B Eldridge, The Second Circuit Sentencing Study: A Report to the Judges of the Second Circuit, Washington, DC: The Federal Judicial Center, 1974, 14).

${ }^{16}$ A particularly sophisticated study in this regard is J Hogarth, Sentencing as a Human Process, Toronto: University of Toronto Press, 1971. For a mixed methods study using case files, courtroom observation and interviews with decision-makers, see J Rumgay, "Custodial Decision Making in a Magistrates' Court: Court Culture and Immediate Situational Factors", (1995) 35 British Journal of Criminology 201.

${ }^{17}$ For the U.S. context, see e.g. L P Sutton, Federal Sentencing Patterns: A Study of Geographical Variations, Utilization of Criminal Justice Statistics Analytic Report 
noted that the standard disposals of certain frequently committed crimes, such as drink-driving or speeding offences, differed markedly between regions and sometimes even between neighbouring courts. ${ }^{18}$ Another frequent finding is (apparent) differences in the sentencing patterns of urban and rural courts for comparably serious crimes. ${ }^{19}$ Sometimes marked differences in the handling of factually comparable cases were observed even between different benches and/or individual judges of the same court. ${ }^{20}$ At the same time, research has established that court practitioners (defence lawyers, prosecutors, probation report writers, and of course judges) do not usually find it difficult to identify "the ballpark" in which a particular case falls. ${ }^{21}$

Footnote 17 continued

No 18, Washington, DC: U.S. Department of Justice, 1978 (available at https:// www.ncjrs.gov/pdffiles1/Digitization/33685NCJRS.pdf) and J T Ulmer and B D Johnson, "Organizational Conformity and Punishment: Federal Court Communities and Judge-Initiated Guideline Departures", (2017) 107 Journal of Criminal Law and Criminology 253. For Germany, relevant studies are discussed in W Frisch, "From Disparity in Sentencing Towards Sentencing Equality: The German Experience", in this issue, text at notes 15 to 23. For England and Wales, see esp. T Mason et al, Local Variation in Sentencing in England and Wales, London: Ministry of Justice, 2007 (finding some variation in average custodial sentence lengths and large variations in respect of custody rates in Magistrates' Courts and the use of life imprisonment and imprisonment for public protection sentences in the Crown Courts across the 42 Criminal Justice Areas (CJAs) in England and Wales, with that variation largely attributable to "marked exceptions...in a small number of CJAs" whilst "the majority of CJAs issued sentences broadly in line with the national average" (ibid, 6 and 11)). An earlier Home Office Research Study had not found any indications of strong regional variations in sentences imposed in Crown Courts for various serious crimes (D Moxon, Sentencing Practice in the Crown Court, Home Office Research Study No. 103, London: Home Office, 1988, esp. 57-59).

${ }^{18}$ See e.g. R Hood, Sentencing the Motoring Offender: A Study of Magistrates' Views and Practices, London: Heinemann, 1972; H Schöch, Strafzumessungspraxis und Verkehrsdelinquenz: Kriminologische Aspekte der Strafzumessung am Beispiel einer empirischen Studie zur Trunkenheit im Verkehr, Stuttgart: Enke, 1973.

${ }^{19}$ T Austin, "The Influence of Court Location on Types of Criminal Sentences: The Rural-Urban Factor”, (1981) 9 Journal of Criminal Justice 305.

${ }^{20}$ For relevant studies of Magistrates' Courts, see e.g. R Hood, Sentencing in Magistrates' Courts: A Study in Variation of Policy, London: Tavistock, 1962; R Tarling, Sentencing Practice in Magistrates' Courts, Home Office Research Study No. 56, London: HMSO, 1979; R Tarling, "Sentencing Practice in Magistrates' Courts Revisited", (2006) 45 The Howard Journal 29. See also N Hutton and C Tata, Patterns of Custodial Sentencing in the Sheriff Court, Edinburgh: The Scottish Office Central Research Unit, 1995.

${ }^{21}$ This observation is ubiquitous in the empirical literature. See e.g. N Hutton, "Reflections" in Tata and Hutton, fn. 4 above, 575, 578. 
Sentencing takes place against a backdrop of strong local conventions of which participants are aware. ${ }^{22}$ Such conventions do, however, remain localised unless particular efforts are made to align them across districts. While some legal systems appear committed to eradicating such regional variation in sentencing, ${ }^{23}$ others do not appear to perceive this as particularly problematic. Some may even view this as reflecting legitimate judicial responsiveness in sentencing to regional variations in the frequency of commission and the local public's perception of certain types of crimes.

Where legal systems permit such submissions, it is well known that sentencing outcomes are strongly influenced by prosecutors' submissions regarding sentence. ${ }^{24}$ General instructions given to prosecutors regarding charging practice and sentencing submissions increase consistency of prosecutorial decision-making and courtroom agency, and thereby indirectly the similarity of sentencing outcomes. Prosecutors' submissions as to sentence may function not merely as a heuristic anchor ${ }^{25}$ (as they invariably will) but may quite consciously

${ }^{22}$ See e.g. M J Lipetz, "Routine and Deviations: The Strength of the Courtroom Workgroup in a Misdemeanour Court", (1980) 8 International Journal of the Sociology of Law 47; J T Ulmer, Social Worlds of Sentencing: Court Communities under Sentencing Guidelines, Albany: State University of New York Press, 1997; D B Johnson, "The multilevel context of criminal sentencing: Integrating judge and county level influences in the study of courtroom decision making", (2006) 44 Criminology 259. For Germany, see W Langer, Staatsanwälte und Richter. Justizielles Entscheidungsverhalten zwischen Sachzwang und lokaler Justizkultur, Stuttgart: Enke, 1994.

${ }^{23}$ Clearly, concern about local variation in sentencing is one of the motivating forces behind the introduction of guideline systems, along with heightened predictability of sentences, better legislative/administrative control of sentence levels, and eradication of inter-judge disparity ascribed to idiosyncracies of judges' personalities and viewpoints.

${ }^{24}$ See e.g. B Englich and T Mussweiler, "Sentencing Under Uncertainty. Anchoring Effects in the Courtroom", (2001) 31 Journal of Applied Social Psychology 1535; A Britton, Pressing for Sentence? An Examination of the New Zealand Crown Prosecutor's Role in Sentencing (30 September 2016). Available at SSRN: https://ssrn.com/abstract $=2996867$.

${ }^{25}$ Psychological studies suggest that people deciding under uncertainty have a tendency to unreflectively latch on to an initially suggested figure/outcome (the "heuristic anchor") and treat this as a starting point from which they make adjustments. It follows that if the initial suggestion had been different the same decision maker would likely have reached a different outcome. 
be treated as a de facto ceiling on the imposed sanction, with further conventions on what is a normal and an unusual "discount" governing judges in the actual apportionment of punishment. ${ }^{26}$ That said, if general instructions to prosecutors are drawn up and issued at district or regional level, their effect may not only be to standardise outcomes within the district or region concerned but also to reinforce and cement variations of outcomes across districts or regions. ${ }^{27}$

It is in studies of individual judges' sentencing practices that researchers have most often found indications of unwarranted discrepancy. ${ }^{28}$ Saks and Hastie memorably comment that "It is something of an embarrassment to observe the great range of sentences that different judges assign to apparently indistinguishable crimes." ${ }^{29}$ Studies that have established such significant variations between different sentencers (listed here in declining size of the group of participants) include Streng $\left(522^{30}\right)$, Palys and Divorski $\left(206^{31}\right)$,

${ }^{26}$ See e.g. P Van Duyne, "Simple Decision Making" in Pennington and Lloyd-
Bostock, fn. 11 above, 143, 145. The same can be said for Germany.
${ }^{27}$ Frisch describes efforts made in Germany in respect of some offences to align
instructions given to prosecutors across the German regional states. See Frisch, fn. 17 above, text at note 66 .

${ }^{28}$ Many of these studies compare average sentence lengths by judges with presumptively comparable case loads over a period of time, using tests of varying sophistication to ensure comparability. For a recent study of this type, see J M Anderson, J R Kling and K Stith, "Measuring Interjudge Sentencing Disparity: Before and After the Federal Sentencing Guidelines", (1999) 42 Journal of Law and Economics 271 (also reviewing earlier studies of this sort).

${ }^{29}$ M J Saks and R Hastie, "Social Psychology in Court: The Judge" in H R Arkes and K R Hammond (eds), Judgment and Decision Making, New York: Cambridge University Press, 1986, 255, 271.

${ }^{30}$ Streng's participants were a mixture of judges, prosecutors and legal trainees. See Streng, fn. 14 above, 75.

${ }^{31}$ Palys and Divorski's participants were 206 judges of the Canadian Provincial Courts (Criminal Division) of whom 45 per cent had been on the bench for less than five years, 25 per cent for 5 to 10 years, 18 per cent for 10 to 15 years and 12 per cent for more than 15 years. In total there were approximately 1,000 judges of this type at the time. See Palys and Divorski, fn. 9 above, 351. 
Hogarth $\left(71^{32}\right)$, Gibson $\left(26^{33}\right)$, Maguire $\left(15^{34}\right)$, and Fitzmaurice and Pease $\left(2^{35}\right)$.

Hogarth's and Gibson's studies correlated outcomes of actual sentencing decisions made by participating judges with in-depth interviews designed to establish social and personal background factors, and attitudes. Streng, Palys and Divorski, Maguire, and Fitzmaurice and Pease used vignettes. These studies provide us with important data to answer two questions: (1) in respect of which types of cases is diversity (where diversity is found) most pronounced, and (2) how strongly is this diversity linked to differences in individual judges' sentencing philosophies (the penal-philosophical approach and attitude of the individual judge)?

\subsubsection{Locating diversity}

Vignette studies find particularly clear differences between sentencers in "on the cusp of custody" cases where a range of disposal options appears potentially legitimate ${ }^{36}$; this ties in with evaluations of reallife sentencing outcomes. ${ }^{37}$ Studies also find highly divergent patterns in cases where offence and offender considerations pull strongly in

\footnotetext{
${ }^{32}$ Hogarth's participants were 71 full-time magistrates in the province of Ontario out of a total of 78 magistrates in the province who dealt with more than 700 criminal cases per year; a further five magistrates did not meet the caseload threshold. See Hogarth, fn. 16 above, 24-25.

${ }^{33}$ Gibson's participants were 26 district judges from three South-Eastern districts in Iowa. See J L Gibson, “Judges' Role Orientations, Attitudes and Decisions: an Interactive Model”, (1978) 72 American Political Science Review 911, 912-913.

${ }^{34}$ Maguire's participants were 15 of a total of 54 district judges in Ireland. All 54 judges were invited to participate in the research; the participation rate thus lay at 28 per cent. See N Maguire, "Consistency in Sentencing", (2010) 10 Judicial Studies Institute Journal 14, 32.

${ }^{35}$ Fitzmaurice administered a vignette-based questionnaire (which she had already used with 41 university students) to two Crown Court judges she had met at a seminar; she also interviewed these judges. See C Fitzmaurice and K Pease, The Psychology of Judicial Sentencing, Manchester: Manchester University Press, 1986, 89.

${ }^{36}$ As shown by the results of Streng's (fn. 14 above), Palys and Divorski's (fn. 9 above, 358) and Maguire's (fn. 34 above, 42) studies. Fitzmaurice's vignettes were composed of factual variations on a serious rape case well above the custody threshold.

${ }^{37}$ See e.g. R Douglas, "Does the Magistrate Matter? Sentencers and Sentence in the Victorian Magistrates' Courts", (1989) 22 Australian and New Zealand Journal of Criminology 40 and the studies cited in fn. 18 and 20 above.
} 
different directions, especially when the sentencing framework calls for the individualisation of sentences and/or the incorporation of rehabilitative concerns (young offenders ${ }^{38}$ ) or instructs sentencers to avoid custody in respect of certain classes of offender (young; aboriginal; infirm; carer), thus unseating "offence seriousness" as the primary determinant of sentence (a point which is discussed further below). Where a range of optional alternatives to prison as well as a range of optional ancillary disposal options is provided for by law, judges appear to differ quite markedly in the "packages" which they would impose in cases they consider to be of comparable severity. ${ }^{39}$ By contrast, studies tend to find less divergence or even high convergence between different judges in their suggested disposals for cases located at the higher end of gravity. ${ }^{40}$

To some extent, the pattern of divergences is reassuring. The greatest divergences typically arise in relation to cases where reasonable sentencers may well differ. ${ }^{41}$ Consider a particularly stark

${ }^{38}$ Cf Doob and Beaulieu, fn. 12 above.
${ }^{39}$ Palys and Divorski observe that "In the cases in which the possible sentence
range was the lowest ... judges' sentences ran the broadest possible gamut" (fn. 9
above, 358). In Maguire's study, inconsistency in suggested sentencing outcomes was
most marked in the case that all judges considered the least serious one, with 13
different suggested disposals including 7 different types of non-custodial sentence (fn. 34 above, 42). Note that this would amount to "disparity" only if the different sanction packages differed markedly in their severity. This is not obviously the case: it may well be possible to establish a degree of equivalence of the severity of different "sentence packages". This was not a point addressed in the research, where different packages of disposals were equated with sentence disparity.

${ }^{40}$ Maguire, ibid, notes that suggested sentencing outcomes were most consistent for what the participants considered to be the most serious case. High convergence in the actual disposals of serious crimes by German courts emerged in the study by H-J Albrecht, Strafzumessung bei schwerer Kriminalität: eine vergleichende theoretische und empirische Studie zur Herstellung und Darstellung des Strafmasses, Berlin: Duncker \& Humblot, 1994. Similarly, J Pina-Sanchez and R Linacre, "Sentence Consistency in England and Wales: Evidence from the Crown Court Sentencing Survey", (2013) 53 British Journal of Criminology 1118, found only minuscule discrepancies in the sentencing of offenders in assault, burglary and robbery cases after controlling for the potential influence of nine common aggravating and mitigating factors.

${ }^{41}$ This is also true for Streng's study (fn. 14 above), although his findings are less reassuring in other respects. The "wing-span" of difference he found in relation to what should have been a completely straightforward case to sentence (a car dealer with relevant prior convictions sold a car at inflated price after turning back the mileage reading) was relatively wide: 16 per cent of the participants would have imposed a fine, others imprisonment between 1 month and 18 months, with just over 
example from Palys and Divorski's Canadian study. One of their vignettes concerns an 18-year-old Native Indian from a "stereotypically deprived background" with a previous record of low-level offending who, together with a 29 -year-old white man, commits a burglary at the home of an elderly couple who are held at gun-point, severely beaten and tied up. (Later in the same paper Palys and Divorski refer to the facts as describing "a horrific offense which generated terror and humiliation in two elderly individuals in their own home". ${ }^{42}$ Unfortunately one cannot get the flavour of the vignette fully as the published research only includes brief summaries of the much richer vignettes presented to the participants. ${ }^{43}$ ) Proposed sentences for this offender ranged from a suspended sentence to 13 years imprisonment, with a median of 6 years imprisonment. ${ }^{44}$ One potentially very significant legal factor (which Palys and Divorski fail to draw the reader's attention to) is that Canadian law contains an explicit provision instructing courts to consider "all available sanctions, other than imprisonment, that are reasonable in the circumstances ... for all offenders, with particular attention to the circumstances of Aboriginal offenders" (section 718.2(e) Canadian Criminal Code). This provision is interpreted as requiring judges to use a different, maximally prison-avoiding, approach to sentencing for aboriginal offenders. ${ }^{45}$

\section{Footnote 41 continued}

a third of these willing to suspend it. One must, however, bear in mind that the participants in Streng's study weren't all judges but included prosecutors (who, as a group, tend to ask for higher sentences than judges eventually impose) as well as law graduates undergoing the second (practical) phase of their legal training. The "outliers" may well have come from this last group - perhaps suggesting that the inexperienced judge may be the greatest risk factor in sentencing.

42 Palys and Divorski, fn. 9 above, 352 and 360.

${ }^{43}$ As Palys and Divorski detail in another publication reporting on the same study: "The case descriptions were intended to be as comprehensive as possible and hence included a fairly detailed description of events leading up to the crime, a full pre-sentence report on the accused (including prior record and social history), and information concerning the effects of the crime on the victim." See T S Palys and S Divorski, "Judicial Decision-making: An Examination of Sentencing Disparity Among Canadian Provincial Court Judges" in D J Müller, D E Blackman and A J Chapman (eds), Psychology and Law, Chichester: John Wiley and Sons, 1984, 333, 335.

44 Palys and Divorski, fn. 9 above, 354.

${ }^{45}$ R. v. Gladue 1999 CanLII 679 (SCC), [1999] 1 S.C.R. 688 clarifies that the aboriginal heritage factor must be given weight in sentencing of all offences by such offenders, no matter how serious, albeit that in respect of the most serious offences, 
The extreme discrepancy found in this case may then well reflect the study participants' good faith efforts to follow the law's impossible-to-follow guidance of keeping indigenous offenders out of prison while still giving weight to the seriousness of their offending behaviour and the risk they pose to the public - resulting in a willingness to interpret the instruction of the law as an instruction to exercise what would otherwise be undue leniency, further encouraged by the young age of the offender in question. Legal provisions of this kind force judges to make what in effect is a "pathway determination" in the case before them. The inevitable result is strongly divergent outcomes which may then mask what may well be complete agreement between all judges concerned that the case is finely balanced and could be taken down either fork in the road. Unless one wants to prohibit legislatures from creating such "pathway options" altogether, one has to accept that these will increase outcome disparity even among decision makers who are in substantive agreement about what matters to the decision at hand and how to weigh and balance the relevant factors against each other.

This observation is of wider application. Where the law offers sentencers a choice of (not obviously equivalent) disposals, and/or where sentencers are instructed by law to give decisive weight to factors beyond the gravity of the offending behaviour as such that have to be put on different sides of a metaphorical scale, sentencers are eventually forced to let one side of the scale determine the outcome. This means that even if sentencers agree that the scales are finely balanced, their subsequent decisions will not reflect the proximity of their initial perceptions and evaluations. For each of them, the set of factors on the preferred side of the scale will feed into the outcome whereas the factors on the lighter side of the scale will no longer be reflected in the sentence. Take a sentencer who must choose between sentencing a young adult "as a young offender", or "as an adult" (this is what trial judges in Germany are instructed to do under section 105(1) of the Youth Courts Act (Jugendgerichtsgesetz, short $J G G$ ) in cases where the defendant was between 18 and 20 years old when he committed the crimes in question). Different sentencers

\footnotetext{
Footnote 45 continued which call for protection of the public, denunciation and deterrence, aboriginal factors may play less of a role. This decision post-dates Palys and Divorski's study. It stands to reason that at the time of their study there may have been significant disagreement among judges about how much weight should be accorded to the aboriginal heritage factor in a serious case.
} 
may not differ much in how they in a given case assess the factors that affect this determination (say, the degree of personal maturity of the offender). But once they have made their determination of which sentencing regime should be applied, given the deep differences between those regimes, their actual sentences will differ vastly.

Returning once again to Palys and Divorski's aboriginal offender, it is plausible to assume that the participants who "sentenced" this hypothetical 18-year-old did not disagree all that strongly on how bad the crime was, or how culpable the offender. But they had to bear in mind the offender's relative youth and the policy of the law to keep aboriginal offenders out of prison (thus loosening the link between crime seriousness and sentence severity for these offenders). We should not be surprised if some decided that the case still fell on the "leniency remains possible" side whereas others thought that it did not. ${ }^{46}$ A case with these features would be difficult to sentence in real life, and very little can be drawn out from how people sentence it in the abstract. In real life sentencers would undoubtedly try to bore deeper into how the crime happened and who the person before them was before settling on their view of the appropriate sentence.

\subsubsection{Explaining diversity}

One question that has stood behind many of these studies is whether a judge's personal views on the purposes of punishment makes a significant difference to sentencing outcomes. Judges clearly differ in their penal philosophies and attitudes. What is, however, less clear is whether and how these differences in attitudes filter through into individual case disposals. Gibson's research suggested that the potential relevance of a judge's general social and political attitudes on sentencing outcome depended on the judge's conception of his role. ${ }^{47}$ One of the often-quoted findings of Hogarth's study of the sentencing behaviour of magistrates in Ontario, which was designed to tease out differences in the personal penal philosophies held by magistrates and their effect on sentencing behaviour, ${ }^{48}$ is that "variation in sentencing behaviour" (such as preferences for fines over probation, and vice versa) was indeed "associated with variation in the attitudes of the magistrates concerned". ${ }^{49}$ However, when Hog-

\footnotetext{
${ }^{46}$ Palys and Divorski also highlight that disparity will be greatest when offender and offence information strongly pull in different directions (fn. 9 above, 359).

${ }^{47}$ Gibson, fn. 33 above.

${ }^{48}$ Hogarth, fn. 16 above.

${ }^{49}$ Hogarth, ibid, 365.
} 
arth linked penalty selection to fact patterns it emerged that "the facts most closely associated with length of sentence are the length of criminal record and the severity of the crime". ${ }^{50}$ Moreover, from the over 2,400 sentencing study sheets that the participating magistrates had filled in, and in which they had reported on their reasons for sentence in these cases, it was clear that "neither penal philosophy nor the attitude scales distinguished magistrates in terms of the ratings given to the severity of criminal acts". ${ }^{51}$ That said, an effect could have arisen by an indirect rather than a direct route. The magistrates' "[p]enal philosophy and attitude scores" were "closely associated with the amount of premeditation seen in the commission of offences, and in the perceptions magistrates formed about offenders' attitudes toward their involvement." ${ }^{, 52}$

The sentencing study sheets also indicated that some magistrates rather crudely gave top weight to their preferred penal purpose in every case that came before them. ${ }^{53}$ But while this might lead one to suppose that the actual sentences imposed by magistrates of different penal-philosophical orientation would diverge strongly, the surprising result was that no strong divergences of this kind were found. Instead, "It appeared that different magistrates can achieve similar sentences through quite different mental routes." ${ }^{54}$ Hogarth himself interpreted his data as establishing that "the judicial process is not as uniform and impartial as many people would hope it to be". ${ }^{55}$ While this may be so, the strongest link he found appears to have been between magistrates' individual sentencing philosophy and sentence explanation, not between their sentencing philosophy and sentence severity as such. Put differently: The judges' differing commitments to different penal aims were most markedly connected to how they explained and justified the chosen sentence, and to how they integrated their sentencing decisions with their self-image. ${ }^{56}$ Actual sentence severity, by contrast, was less closely linked to the judges' penal

\footnotetext{
${ }^{50}$ Hogarth, ibid, 348.

${ }^{51}$ Hogarth, ibid, 274.

${ }^{52}$ Hogarth, ibid, 274.

${ }^{53}$ Hogarth, ibid, 289.

${ }^{54}$ Hogarth, ibid, 289-290.

${ }^{55}$ Hogarth, ibid, 365.

${ }^{56}$ See also Hogarth, ibid, 299 (suggesting that magistrates may mentally "rearrange the facts to fit the types of sentences they use habitually") and his discussion at 376-378. Palys and Divorski also observe that "it appeared that many, if not most judges perused case facts, chose salient ones, formulated legal objectives on this
} 
attitudes than it was to perception of certain facts which are standardly accepted as relevant.

Various other studies support the conclusion that actual sentences are correlated more closely to perception of such facts, than they are to penal attitudes. Fitzmaurice, in her small pilot study with two crown court judges who she asked to "sentence" a series of paper cases, found that "in the case of these two judges, 77 per cent and 98 per cent of variation in the sentence length was accounted for by variation in judgments of offence seriousness." ${ }^{25}$ Findings from studies that combine qualitative interviews of judges with sentencing case vignettes present a similar picture. ${ }^{58}$ While this provides some reassurance that sentencers indeed base their sentencing decisions on the gravity of the offending behaviour, it also suggests an entry point for hidden disparity. As Hogarth's findings have already reminded us, judgements of offence seriousness and offender culpability are themselves not neutral or beyond the influence of differences in penal attitudes. ${ }^{59}$ Sentencers' differing perceptions of offence seriousness and offender attitude will quite obviously result in punishments of differing severity.

Another important source of unequal punishment for comparable crimes is the difficulty of translating perceived levels of offence seriousness into sentences of matching severity. This also emerged in Fitzmaurice's pilot study, with Fitzmaurice observing that even judges who agree in their assessment of offence seriousness may diverge in their notions of the rate at which the severity of punishment in-

\section{Footnote 56 continued}

basis, and then proceeded to 'repackage' case facts in a manner which showed maximal harmony between legal objectives and case facts" (fn. 9 above, 358).

${ }^{57}$ Fitzmaurice and Pease, fn. 35 above, 58.

58 Offence seriousness was the best predictor of actual sentencing outcomes in Sutton's 1978 evaluation of the sentencing patterns of different US courts (fn. 17 above); it also regularly emerges as the variable with the strongest explanatory value in mixed methods studies such as Hogarth's (fn. 16 above). See further the findings of Jan de Keijser's study with Dutch magistrates (JW de Keijser, Punishment and Purpose. From Moral Theory to Punishment in Action, Leiden: Thela Thesis, 2000). S Wheeler, K Mann and A Sarat concluded on the basis of interviews with 51 U.S. Federal judges that the sources of disparity lie not in a lack of sentencing principles but in variation in the ways these are transformed into actual sentences (Sitting in Judgment: The Sentencing of White-collar Criminals, London: Yale University Press, 1988). Compare also the study by Palys and Divorski, fn. 9 above.

${ }^{59}$ Consider the already-mentioned link that Hogarth found between sentencing philosophy and perceptions of culpability. 
creases with its length. While hardly any sentencer appears to believe that, in order to double the severity of a prison sentence, one needs to impose a sentence of "twice the length" of the first sentence, they compress the length of the sentences they add in order to arrive at a "twice" or "three times as serious" punishment to different degrees. Hence substantial differences in sentence length could be accounted for by judges' differing views on what punishment is "twice as serious" as another. ${ }^{60}$ The same point also applies to "conversion rates" between different types of sanctions in systems where sanction types are in certain ranges supposed to be interchangeable. ${ }^{61}$

\subsection{Eradicating diversity?}

This leaves the question whether anything could and should be done to eradicate inter-judge variation in sentencing outcomes. In a perceptive early discussion doubting that disparity undermines confidence in the system, Douglas points out that "a sense that sentences are predictable may not mean that sentences are regarded as just." 62 Instead, sentencing may come to be regarded as "a rather formulaic activity which makes relatively little allowance for what defendants

\footnotetext{
${ }^{60}$ Fitzmaurice and Pease, fn. 35 above, 89-90.

${ }^{61}$ Interestingly, when Streng (fn. 14 above) designed his vignette study, he compared the severity of punishments of different kinds only after "converting" the different types of punishment into comparable units. Where participants proposed the imposition of a fine (which in the German system will be expressed as a set number of "day fines", one day fine being equivalent to the income an offender does or could earn in one day of work), Streng took that number as the unit of comparison (a proposed sentence of "30 day fines" thus equals " 30 "). Where participants proposed a non-suspended sentence of imprisonment, Streng applied a multiplier of 4 to the length of imprisonment to find the unit of comparison (a proposed "nonsuspended prison sentence of 1 month (30 days)" thus equals "120"). The conversion rate between day fines and suspended sentences of imprisonment was multiplication by 2. This was Streng's rough-and-ready way of giving quantitative expression to conventional beliefs about the relative seriousness of different types of punishment. Needless to say, different individual participants might have picked very different personal multipliers, had they been asked. Streng's conversion rate approach does, however, reflect the deep-seated belief among practitioners that these sentence options are not of equivalent but of ascending severity, despite the fact that they are equated 1:1:1 by the relevant legislative provisions. On this, see further S Harrendorf, "Sentencing Thresholds in German Criminal Law and Practice: Legal and Empirical Aspects", in this issue, text at nn. 13-16 and 20-29.

${ }^{62}$ Douglas, fn. 37 above, 51. Other scholars also argue that it is unclear that "such disparities should be troubling per se" (R A Bierschbach and S Bibas, "What's Wrong with Sentencing Equality”, (2016) 102 Virginia Law Review 101, 108).
} 
may regard as the special feature of their cases", resulting in "condemnation of a system ... perceived as overly rigid and as characterised by a refusal to recognise the distinctive features of each crime and each defendant." 63

In the next Part, we shall look at whether, and if so why, we have reason to want relatively high levels of judicial discretion in the system.

\section{THE CASE FOR SUBSTANTIAL SENTENCING DISCRE- TION: RESPONSIVENESS AND RESPONSIBILITY- TAKING IN THE COURTROOM}

\subsection{The Conventional Case for Sentencing Discretion}

Judges often claim that broad sentencing discretion is crucial to their ability to sentence offenders appropriately but it can be difficult to explain why this is so. The most frequently heard arguments invoke the "uniqueness" of each case, the preservation of judicial independence, and mercy. Let us take a closer look at each of these.

\subsection{1 "Uniqueness"}

Stated without further elaboration, the argument that wide sentencing discretion is necessary in order to enable judges to respond adequately to the uniqueness of each case is quite weak. It is, of course, undeniable that no two cases are exactly identical, and that any legal rule is open textured enough to leave some leeway in its interpretation and application. But it is equally true that many of the differences observed in respect of facts that matter for the sentencing decisions are too minute to signal that a distinction between these cases would be appropriate on account of this difference. The "uniqueness" of cases, moreover, cannot be seen as a denial of the possibility of making comparisons between cases. Quite the contrary. Regarding the "method" by which judges arrive at the sentence they impose in an individual case, it is well known that sentencers sentence "comparatively" by relying on what they believe are similarities between cases - and that it is this pattern of perceived similarities which in fact enables practitioners to develop through experience and communi-

${ }^{63}$ Douglas, ibid. A growing body of evidence from the U.S. discussed in subsection 2.4 below suggests that this has indeed been the case. 
cation such a clear sense of the area in which an individual case falls. ${ }^{64}$ Empirical studies of sentencing suggest that sentencers maintain consistency and achieve predictability by working with what is essentially an analogical or associational method: they find the appropriate range/starting point for a sentence in any particular case by grouping the case with other cases they perceive to be of comparable severity. ${ }^{65}$ As Hutton explains:

Judges are aware that they are members of a profession and co-workers in a local criminal justice community. Court practitioners, including judges, have a shared tacit understanding of the tariff. While they would find it very difficult to describe this tariff explicitly, they would have little difficulty in reporting from their own experience cases which they felt departed from the tariff. They know that one of the demands of justice is consistency. Part of their job as sentencers is to try to treat like cases alike both in terms of their own personal sentencing practice and in terms of the practice of other judges. In other words, the notional 'tariff' which is produced through the negotiations of court actors forms a structure underpinning the sentencing decision making of sentencers. ${ }^{66}$

To recognise that "the act of sentencing is fundamentally a comparative process ${ }^{\$ 67}$ points to an inherent limitation of grounding sentencing discretion in the alleged uniqueness of cases. Discretion-based sentencing itself only works as a practice because it can rely on court practitioners' perceptions of similarities between cases - what Tata has felicitously called "typical whole case stories"68 - and the knowledge of the individual judge of how she, and her peers, have previously dealt with similar cases. It is therefore not immediately evident what would be lost if a standardisation of punishments structured around something like a "typical case" model were to be attempted.

${ }^{64}$ This was apparently first pointed out by Hood in his study of the sentencing practice of magistrates (Hood, fn. 20 above, 16).

${ }^{65} \mathrm{C}$ Tata, "Conceptions and Representations of the Sentencing Decision Process", (1997) 24 Journal of Law and Society 395, 396. For Germany, Schier has remarked that "What emerges in practice is a system of comparative sentencing in conjunction with the rest of the judiciary" which has a high level of support from the judges he interviewed, especially regarding sentences for less serious and very frequent types of cases (J-T Schier, Die Bestimmtheit strafrechtlicher Rechtsfolgen, Berlin: Lit Verlag, 2012, 219).

${ }^{66}$ Hutton, fn. 21 above, 578.

${ }^{67}$ Tata, fn. 65 above, 396.

${ }^{68}$ Tata, ibid, 412. Interchangeably, Tata also speaks of "typical whole offence stories". 


\subsubsection{Judicial independence}

Another argument frequently put forward to ground the case for substantial sentencing discretion is that of judicial independence. Before the introduction in England and Wales of a duty on every court to "follow any sentencing guidelines ... relevant to the offender's case ... unless the court is satisfied that it would be contrary to the interests of justice to do so" (section 125(1) of the Coroners and Justice Act 2009), the Magistrates' Association criticised an earlier draft of this provision as a threat to judicial independence. Ashworth called this a "strange and unsupportable use of that concept [of judicial independence]" since "Nothing in the Bill prevented courts from deciding cases impartially, without fear or favour", and, while the Bill did set out to constrain sentencers' discretion, "there is no doubt that Parliament may lawfully create mandatory sentences if it wishes" which he considered "regrettable, but not unconstitutional."69

But this may be too quick a dismissal of this point. The reference to judicial independence here may have to be read more broadly, as a reference to the appropriate division of roles between judges, legislators, and governments in collectively providing citizens with a system of government that is respectful of people's dignity and rights. The proper performance of the judicial function may require more than that decision makers avoid favoritism and need not fear reprisals or be motivated by the prospect of rewards for decisions that would curry favour with the government. We may be rightly concerned at the prospect of a system where sentencing judges merely "pronounce" sentences that have already been decided upon by other people, elsewhere. This is a point we will need to return to in our subsequent discussion, after stating briefly the third most frequently used argument in defence of broad sentencing discretion.

\subsubsection{Mercy}

Wide sentencing discretion is sometimes defended in order to make room for mercy. But mercy, as one of the judges interviewed by Brown in his recent exploration of sentencing practice in Scotland makes clear, is in issue only after the usual range of mitigating factors has been considered, and exhausted. ${ }^{70}$ While an important safety

${ }^{69}$ A Ashworth, "The Struggle for Supremacy in Sentencing", in Ashworth and Roberts, fn. 6 above, 15, 30 .

70 "Mitigation gets you to your headline sentence, taking everything into account. Mercy would then come in when, having considered everything, you think, well, that is the sentence that is appropriate for that person in all the circumstances of this 
valve - allowing the judge to recognise that there are things in this world more important than punishment of the guilty, and that the case in front of her falls into this category - it is thus invoked by a sentencing judge in comparatively few and rather exceptionally structured cases. In Jacobson and Hough's study of mitigation, one of their respondents "described as 'showing mercy' his decision to pass an unexpectedly short custodial sentence on a prolific burglar whose long-term partner was clearly in the late stages of terminal cancer", 71 and this indeed provides an excellent example of how mercy operates in sentencing as an independent public value. What perhaps is still in some sense an unduly lenient sentence is passed because we should all prefer to live in a world where someone, prolific burglar or not, should not be forced to abandon a very sick partner in the final months of their partner's life. Avoiding such an outcome not only shows compassion for the partner but, just as importantly, acknowledges the defendant as someone whose ethical existence cannot be reduced to the "life of crime" he leads but also involves forming important interpersonal relationships and doing his duty by those to whom he stands in such relationships. ${ }^{72}$

The case for substantial sentencing discretion to exist in every case that comes before a judge, however, must rest on something else. To develop it properly, we need to ask about the function of the sentencing judgment, which is the issue to which I turn next.

Footnote 70 continued case." G Brown, Criminal Sentencing as Practical Wisdom, Oxford: Hart/Bloomsbury, 2017, 87 (quoting a Scottish sheriff).

${ }^{71} \mathrm{~J}$ Jacobson and M Hough, Mitigation: The Role of Personal Factors in Sentencing, London: Prison Reform Trust, 2007, 40.

${ }^{72}$ Classic other instances where sentencers exercise mercy are in sentencing offenders whose offending behaviour has already resulted in overwhelming personal costs (say, the traffic offender whose own child was killed in the resulting accident) and offenders whose health is so miserable that they cannot receive adequate treatment or would die in prison. Mercy in this sense responds to what von Hirsch and Ashworth call "equity factors" at sentencing. Von Hirsch and Ashworth consider responsiveness to equity factors legitimate when and to the extent that the compassion or sympathy shown to the offender "rests on quasi-retributive grounds, related to the values underlying the desert rationale" (A von Hirsch and A Ashworth, Proportionate Sentencing: Exploring the Principles, Oxford: Oxford University Press, 2005, 175). To my mind equity factors are best understood and justified more broadly as factors that, in a system that has retained a sense of the relative moral importance of state punishment versus other morally important aims and values, should lead to a de-emphasising of the need to punish. 


\subsection{The Function of the Sentencing Judgment}

Consider a typical penal sentence, where a person is convicted of, say, residential burglary and theft of goods worth $£ 100$, and as punishment is sentenced to a fine of $£ 500$ and $50 \mathrm{~h}$ of community service. Three interrelated points are worth observing.

First, this is clearly a special kind of judgment: it is, as one might say, "creative" of legal relations in a way that most other court judgments are not. Think, by way of contrast, of an action for payment of an agreed sum under a contract. The judgment in favour of the claimant merely "finds" that the defendant is obliged to pay this sum; it does not as such bring this obligation into being. The obligation to pay the specified sum under the contract already existed before judgment was rendered; the judgment merely confirms that this was so. Similarly, when an action for damages in tort is brought, the obligation that is being enforced - although not identical to the primary obligation which the defendant tortiously breached - is in a direct, logical way linked to the primary obligation: it continues the primary obligation in a transformed shape. For this very reason, it can be effectively fulfilled even in the absence of a court order. My payment of the sum that it takes for you to repair your car which I bumped into when reversing my car fulfils the (secondary) obligation that has arisen from my breach of my (primary) obligation to drive my car with due care and attention, and it does so whether or not I pay up immediately or only after you have successfully sued me for damages. By contrast, the legal relationship that obliges the burglar in our example to undergo the specified punishment is created only by the sentence passed by the trial court. ${ }^{73}$

This leads to the second observation. When a court sentences an offender, the punishment for the crime is necessarily of the court's making. ${ }^{74}$ Whereas the defendant in our example was "liable to

${ }^{73}$ To be sure, the criminal court's sentencing decision is not uniquely special in this way. Some judgments rendered in the civil courts also create new legal relations between the parties (a judgment setting out arrangements post-divorce may be a case in point). Note also that, in criminal matters, the relevant legal relationship may sometimes be created by other institutional actors exercising an authority vested in them to dispose of this kind of case. Moreover, where the system provides for the diversion of certain cases to non-institutional settings the legal relationship can arise from a settlement reached in this diversionary (usually restorative justice) framework.

${ }^{74}$ As a technical legal point this has been observed long ago by German writers on criminal procedure. See e.g. E H Rosenfeld, Der Reichs-Strafprozess: Ein Lehrbuch, Berlin: De Gruyter, 1912, 31. The same point applies to other institutional (or institutionally authorised) actors who conclude a criminal case by way of a binding sanctioning response. 
punishment" for his burglary from the very instant he committed his crime, he only became liable to "pay a fine of $£ 500$ and undergo $50 \mathrm{~h}$ of community service" in respect of it once the trial court had ruled that this is to be his punishment. The commission of the crime has no automatic effect in bringing a particular punishment down upon the offender's head. What the crime brings about is merely the creation of a vulnerability (or, if you prefer, "liability") to being punished according to law. It authorises an official punitive reaction but it also needs a sentencer to give effect to this by determining the sanctioning response in the individual case.

The first and second point have to do with a third feature of criminal punishments: There is no obvious or self-evident way in which breaking and entering into another person's premises and taking away some of their things from them "equates to" or "translates into" a payment of $£ 500$ to the state, and $50 \mathrm{~h}$ of community service. The reason this is so is because (to the extent that doing these things is a burden on the offender), this is not a burden or harm that has already been brought about by the criminal act. Penal sentences do not reallocate existing harms. They are burdens that are freshly created in response to the crime.

The creative dimension of the penal sentence suggests that we ought not to look at it as merely executing a sanction already incurred by the commission of the crime. Rather, the sentence is part of an interaction that is irreducibly not merely past- but also future-oriented. Looking forward, the sentence of the trial court sets the terms for the polity's continued relationship with an offender in respect of his offence. When the burglar in our example is sentenced to a fine of $£ 500$ and $50 \mathrm{~h}$ of community service, he is in effect told that "Sentencing you to a fine of $£ 500$ and $50 \mathrm{~h}$ of community service lays down the terms on which 'we' - the members of this polity, the 'people' in whose name you are being judged - will continue our relations with you."

Understood as part of an interaction that is not merely backwardbut also forward-looking, sentencing is focused on finding a way forward that is reasonable for all concerned. The "concern is no longer simply what happened during a crime, but also what to do with the convicted criminal in light of his, the victims', and society's needs". ${ }^{75}$ For this reason, as Berman and Bibas point out, sentencing "necessarily incorporates offender-oriented considerations". ${ }^{76}$

${ }^{75}$ D A Berman and S Bibas, "Making Sentencing Sensible", (2006) 4 Ohio State Journal of Criminal Law 37, 54-55.

${ }^{76}$ Berman and Bibas, ibid. 
Empirical research on sentencing can tell us a lot about how such considerations can be incorporated into the sentencing decision, and it is to this research that I now turn.

\subsection{Offender-Oriented Considerations at Sentencing}

Two prominent themes emerge in courtroom observations and judicial interviews: (1) How hard judges try to avoid imprisoning offenders, and (2) how strongly judges strive to build up a picture of the person in front of them, believing this to be crucial for the sentencing decision they are about to make. A third, connected issue is trying to understand what motivates these efforts.

\subsubsection{Avoiding imprisonment}

As the Canadian judge Renee Pomerance pointed out: "Many of us have seen cases in which an offender 'on paper' is deserving of a jail term but 'in person' is deserving of another chance." ${ }^{77}$ But how do judges arrive at that conclusion?

Hough, Jacobson and Millie conducted an extensive study of courts' decisions in "on the cusp" cases where sentencers believed that the case might potentially call for a custodial sentence. Their courtroom observations led them to conclude that:

In cusp decisions, it was clear that sentencers were casting around for some reason to avoid a custodial sentence. This could be an indication - of any kind - that a prolific offender was willing and able to change his or her offending behaviour, or that a first-time offender would not offend again. In a sense, therefore, the process of sentencing of cusp cases can become a search for hope - even a glimmer of hope - that can justify a non-custodial sentence. ${ }^{78}$

One of Tombs and Jagger's respondents in their study of decisions to imprison similarly stressed that he would "look for 'something' that indicates that there was 'real hope' - a 'real prospect [of rehabilitation], not a pie in the sky sort of thing ... that's what would persuade me to go for a community sentence"". ${ }^{79}$ Such efforts to avoid custody whenever a sentencer perceives that a plausible custody-avoiding

\footnotetext{
${ }^{77}$ Justice R M Pomerance, "The New Approach to Sentencing in Canada: Reflections of a Trial Judge", (2013) 17 Canadian Criminal Law Review 305, 314.

${ }^{78}$ M Hough, J Jacobson and A Millie, The Decision to Imprison: Sentencing and the Prison Population, London: Prison Reform Trust, 2003, 41.

${ }^{79}$ J Tombs and E Jagger, "Denying Responsibility: Sentencers' Accounts of their Decisions to Imprison”, (2006) 46 British Journal of Criminology 803, 816.
} 
sentencing option exists are made across penal systems. Van Oorschot, Mascini and Weenink concluded, based on ethnographic data gathered in a type of Dutch criminal court where the sentencing powers of the court go up to one year of imprisonment only, that "judges focus on the question whether the defendant has demonstrated that he or she has 'made a change' or 'turned things around in their life" and "seek for evidence that the defendant has truly transformed himself or herself". ${ }^{80}$ In concrete terms, this meant that "the judges studied here routinely check if the defendant has sought help for drug- or alcohol-related issues, for instance, and gauge to what extent the defendant shows himself/herself a 'functioning adult' with a job or a 'meaningful way to pass the day', for example, by going to college or through volunteering." 81

Of course, the existence of legislation that instructs sentencers to explore non-custodial options, and to only impose imprisonment in cases where it is "unavoidable", is part of the backdrop against which sentencers search for alternative disposals. But such legislation is anything but a magic bullet to keep custodial sentences at a minimum. ${ }^{82}$ The motivation for judges to attempt to avoid imprisonment that emerged from these interviews with judges and courtroom observation is that they endorsed this objective morally. This endorsement was in turn rooted in their perception that many of the people before them were "here because of misfortune, mental illness, a combination of them", ${ }^{83}$ misfits rather than crooks, unlucky rather than evil, that prison is a frightening experience for many and often just a way of making their lives go worse, ${ }^{84}$ and that, if they imposed a custodial sentence, it would be their decision to make the defendant's life go worse in this particular way, for which they would have to carry a moral responsibility. ${ }^{85}$ This last point is well expressed by a

${ }^{80}$ I van Oorschot, P Mascini and D Weenink, "Remorse in Context(s): A Qualitative Exploration of the Negotiation of Remorse and Its Consequences", (2017) 26 Social and Legal Studies 359, 365.

${ }^{81}$ Van Oorschot et al, ibid.

${ }^{82}$ See J V Roberts and L Harris, "Reconceptualising the Custody Threshold in England and Wales", in this issue.

${ }^{83}$ Brown, fn. 70 above, 85 (quoting a Scottish sheriff).

${ }^{84}$ For relevant quotes from sentencers, see e.g. Rumgay, fn. 16 above, 205, Tombs and Jagger, fn. 79 above, 808.

${ }^{85}$ Tombs and Jagger, ibid, assert that sentencers find ways of denying their responsibility for this decision. This is their interpretation of sentencers explaining their decision to imprison by saying things like "the point had been reached where 
magistrate in one of Hough et al.'s focus groups, who said that when sending an offender to custody, "it is something that you will reflect, that you have taken the responsibility with a couple of others of depriving someone of their liberty". ${ }^{86}$

In pointing to the fact that the judges observed in these studies were morally "self-motivated" to minimise their use of imprisonment, I do not wish to create the impression that this attitude is universal among judges. Indeed, it is clear that not every judge shares that motivation. ${ }^{87}$ What I want to draw attention to is the connection between the existence of that motivation and the parsimonious use of imprisonment, and the fact that both of these appear to be connected to the extent to which judges engage with offender-oriented factors at sentencing. This last point is addressed further in the next sub-section.

\subsubsection{Seeing offenders for who they are}

The sentencers observed in these studies saw themselves very much as responding to the person of the offender. They wanted to understand the kind of person they were imposing their sentence on. If they had to sentence someone who shared the values of the law and blamed himself for having violated these values, they often opted against custody whereas a non-attuned offender was given a wake-up call. This is again brought out in research from different jurisdictions. Van Oorschot et al. cite a judge who had to sentence "a couple of young guys charged with armed robbery of a store". From their demeanour in court he had concluded that they "were indifferent, they didn't see the gravity of what they'd done." So he sentenced them "accord-

\section{Footnote 85 continued}

custody was unavoidable". To my mind their interpretation is problematic. To say "the point was reached where I simply had no other choice but to do X" is a claim by which one asserts one's responsibility: one has concluded that doing anything other than $\mathrm{X}$ would not be reasonable any more.

${ }^{86}$ Hough, Jacobson and Millie, fn. 78 above, 35.

${ }^{87}$ One respondent in Brown's study indicated that he was quite prepared to impose a custodial sentence on a prolific petty offender with, say, drug abuse issues, to whom some of his colleagues might show greater forbearance, because "It's the ordinary people who need our protection", so no-one can come along thinking that their "choice to be on drugs should entitle [them] to some special favour" (Brown, fn. 70 above, 86). This sentiment may well be shared by a number of other judges. As apparent from this quote, it is connected to a choice on the part of the judge to turn his attention away from the offender to what he perceives to be the interests of the public. 
ingly" - harshly enough for the judge to expect that that would make them understand the seriousness of what they'd done. ${ }^{88}$ Tombs and Jagger from their fieldwork in Scotland mention a case of a 31 year old first offender charged with dangerous driving and drink driving who was sentenced to imprisonment by a sheriff to whom it had become "quite clear that this man had no conception that there was anything really wrong with his driving. He was... sitting there listening to his lawyer talking with an extremely arrogant sort of look on his face, as if to say "what are they worried about?", 89 On the flipside, Jacobson and Hough describe the case of a 47 year old neighbour who after a series of grave disturbances "lost the plot" with the father of the loutish, abusive brood next door and waved a knife at him - and who would have controlled himself better, had he not allowed his drinking to get out of hand. This man clearly genuinely felt bad that he had behaved like this. The incident had been a wake-up call for him to seek help with his drinking. So there was no need for a lesson-teaching, seriousness-asserting message to be sent to him through the act of punishing him. The offender himself completely acknowledged the wrongness of what he had done and had reacted constructively - suggesting to the judges that the reaction of the official system could be milder. ${ }^{90}$

Recognising and responding to moral and practical efforts made by an offender was considered important by sentencers. During the trial and sentencing hearing they looked specifically for signs of redeemability. ${ }^{91}$ A strong indicator of redeemablity could be genuine contrition. One of Jacobson and Hough's respondents commented: "I know there are actors in the dock as much as on stage ... but it's easy to under-estimate the importance of the face-to-face contact you have with the offender - particularly if you take the trouble to make eye contact". ${ }^{92}$ The same respondent then added that "while he might be 'conned' by a defendant pretending to be remorseful, 'I'd rather

\footnotetext{
${ }^{88}$ Van Oorschot, Mascini and Weenink, fn. 80 above, 365.

${ }^{89}$ Tombs and Jagger, fn. 79 above, 816.

${ }^{90}$ Jacobson and Hough, fn. 71 above, 20.

${ }^{91} \mathrm{P}$ Mascini et al, 'Understanding Judges' Choice of Sentence Types as Interpretative Work: An Explorative Study in a Dutch Police Court"(2016) 1 Recht der Werkelijkheid 32 (observing that "Judges select and weigh information to create an image of defendants' redeemability").

92 Jacobson and Hough, fn. 71 above, 48-49.
} 
make that mistake than find a [genuinely] repentant, reformed offender and reject his pleas". 93

When sentencers see it as part of their task to respond to the person of the offender, sentencing acquires aspects of an everyday moral interaction between the offender and the sentencer. In particular, judges have been observed to "try to build up a rapport" with the offender, something that gives them confidence in their more constructive sentencing responses. Jacobson and Hough mention a judge who "talked of a case in which he passed a drug treatment and testing order on a husband and wife who were, he felt, 'worth taking a gamble on'. He has been pleased to see both of them getting themselves into a position to take up employment and to have their six children returned to their care by social services." 94 They also observe that it was not at all rare for judges to reserve breaches of community orders to themselves so that they could see how the offender was doing. These judges, they say, often "build a kind of relationship with the defendant" where they take genuine pride in seeing offenders succeed in getting their lives back on track. ${ }^{95}$

Taken as a whole, the empirical evidence supports the conclusion that the consideration of personal factors in the sentencing context is strongly (albeit not invariably) linked to moderation. ${ }^{96}$ This should not surprise us. Rumgay, whose study of custody decision-making in

${ }^{93}$ Jacobson and Hough, ibid, 49. See also Mascini et al, fn. 91 above, 38 (observing "three types of decisions judges made: first, wherein all signs noticed by judges pointed in the same direction ...; second, wherein judges weighed signs pointing in opposite directions; and third, wherein judges elicited signs of hope and remorse before choosing sentence type").

94 Jacobson and Hough, ibid, 51.

95 Jacobson and Hough, ibid, 50. By pointing to such forms of moral interaction between sentencer and sentenced I do not wish to imply that state punishment can, or should, be construed as a dialogic exchange of the sort postulated by some communicative theories of punishment. This is quite a different question. For a helpful discussion of some of the difficulties these theories encounter, see K Brownlee, "The Offender's Part in the Dialogue" in R Cruft, M H Kramer and M R Reiff (eds), Crime, Punishment, and Responsibility: The Jurisprudence of Antony Duff, Oxford: Oxford University Press, 2011, 54.

${ }^{96}$ Jacobson and Hough, ibid, passim. This has also been the view of the courts: In Williams 337 U.S. 241 (1949), the court suggested that allowing judges to better understand offenders' characteristics and circumstances has "not resulted in making the lot of offenders harder", emphasising that "a strong motivating force... has been the belief that by careful study of the lives and personalities of convicted offenders many could be less severely punished and restored sooner to complete freedom and useful citizenship." (249). 
a city magistrates' court found parsimonious use of custody in a decision-making environment that furthered a "discursive approach" and "favour[ed] personalized information about offenders", explained this finding by drawing attention to a considerable number of studies in which "[e]xposure to individualized, case specific information has been found to attenuate opinions of the offender's culpability and deserved punishment which might be expressed at a general level about a type of crime", and suggested that "Successful mitigation manipulates this process by pointing out information which increases sentencers' attention to, and reasoning about, the circumstances in which a particular offence has been committed." 97 This is probably true both in legal systems where sentencing is a highly regulated and hemmed-in activity and in systems where judges are given considerably more elbow-room. But the prospects that a sentencer will respond appropriately to personal factors are greater in systems that call for a directly value-oriented sentencing decision than in systems that require sentencers to take a more formalistic approach. An important reason for this is that, as Rumgay suggests, "mitigation represents a social psychological process of sympathetic identification with an offender, rather than the accumulation and aggregation of objective facts". ${ }^{98}$ In the reality of sentencers' decision-making, a process of sympathetic identification is more likely to occur when mitigation is not so much a separate stage or checkpoint in a sentencer's deliberations but part and parcel of the sentencer's assessment of the various aspects of the case in the context of arriving at a properly individualised sentence. ${ }^{99}$ The significance of mitigating factors might thus well be suppressed by a more formalistic sentencing regime. Such a regime might moreover require of judges to take account of such factors by way of what the system labels an irregular event - a "downward departure" from what would "in principle" be warranted, as opposed to the main guiding consideration in figuring out what is the warranted response. This might prime

\footnotetext{
${ }^{97}$ Rumgay, fn. 16 above, 208 (references omitted).

98 Rumgay, ibid.

${ }^{99}$ Sentencers might not even think of what they are doing as "mitigation". Jacobson and Hough record their surprise that "many of our respondents were hesitant or reluctant to generalise about the kinds of personal mitigation that influence their sentences", and mention two respondents who initially were unable to comment but who, in one case, later said "the more you think about it, the more factors there are" and, in the other case, "Now I think about it, maybe mitigation does play a bigger part than I first indicated." (Jacobson and Hough, fn. 71 above, 14).
} 
judges to give insufficient weight to such factors even though they are not precluded from looking at them. ${ }^{100}$ Bearing this in mind, a sentencing system that wants to encourage moderate sentencing outcomes would be well advised to provide its judges with substantial sentencing discretion.

\subsection{The Moral Character and Moral Seriousness of Judging}

There is another important reason, to do with the moral dimensions of sentencing, why substantial sentencing discretion is preferable to merely residual discretion. It is clear from the examples given in the previous sub-section that "Sentencing is not so much a technical or value-neutral process as a value-laden process of constructing and exploring the narratives of the lives of the people in the dock."101 Judges themselves describe sentencing as "in substantial part a moral decision". ${ }^{102}$ They also leave their interlocutors in no doubt that they perceive sentencing as an aspect of their work that calls for exercise of their human qualities, as well as, or perhaps even more than, it calls for application of their trained intellect. Lynn Adelman, a Wisconsin district court judge and former Wisconsin legislator, criticises the impact Frankel's notion of "lawlessness in sentencing" has had on judges in the United States for the reason that his ideas

have made them less thoughtful sentencers. Sentencing under numerical guidelines is relatively easy because it requires little reasoning. Judges need not think through the often difficult questions of how the various purposes of sentencing relate to each other in a particular case. Their principal obligation is to calculate the applicable number - a task that generally is a mechanical one. As a result, judges are less able to perform the task of "practical reasoning" in a specific factual context that effective sentencing requires. ${ }^{103}$

${ }^{100}$ One of Ulmer and Johnson's respondents, a public defender, remarked: "The rules do not look as problematic to [newer judges] as they do to somebody who came before them. ... The newer judges ... lean on the Guidelines a lot more than judges did that were on the bench when the guidelines became effective. ... [W]ith these [newer] judges, you really have to show them something that tells them that they should [depart below Guidelines], you know. They still may say, 'Well, I recognize that I have this discretion, but I choose not to use it."'(Ulmer and Johnson, fn. 17 above, 284).

${ }^{101}$ Hough, Jacobson and Millie, fn. 78 above, 39.

${ }^{102}$ L Adelman and J Deitrich, "Marvin Frankel's Mistakes and the Need to Rethink Federal Sentencing”, (2008) 13 Berkeley Journal of Criminal Law 239, 246. 103 Adelman and Deitrich, ibid, 257 (references omitted). 
Like Duff (whom she and her co-author quote) Adelman views sentencing as an exercise of "a kind of judgment that is more akin to perception (seeing what is appropriate or what will make sense) than it is to calculation," 104 an understanding of the sentencing process shared by judges at every level of the judicial hierarchy whose views are quoted in Brown's recent book on "Criminal Sentencing as Practical Wisdom". ${ }^{105}$

Importantly, it is not merely a cognitive but a moral burden which sentencing systems that remove substantial discretion from sentencing judges take off judges' shoulders. This burden is well described by one respondent in Jacobson and Hough's study on personal mitigation, who said that sentencing can be

terrifying, because it's a very subjective exercise - there are all these objective parameters put in place, but in the end it's down to what one person thinks about another. ${ }^{106}$

A U.S. judge described pre-guidelines sentencing as a time when sentencing was "a tremendous moral burden to carry around with you. To pronounce these sentences on people like they're coming out of your head, and that's what you're doing, and you have to sleep with it at night (...)". ${ }^{107}$

To some extent, judges may insulate themselves against the moral burden involved in having to decide another person's fate by finding ways of not thinking too hard about the impact a particular punishment might have on the person before them. For instance, Fitzmaurice and Pease observe that "the use of conventional number preferences in sentencing choice probably protects sentencers from thinking about what a sentence means in practice." 108 But usually these mechanisms at least operate in a context where judges understand their task as sentencers as having to set reasonable terms for continued co-existence with an offender on behalf of the polity, which means that they are expected to take moral responsibility for the judgment as a decision they have reached and stand behind. If fixing the length of a sentence in familiar units of months or years already

${ }^{104}$ R A Duff, "Guidance and Guidelines", (2005) 105 Columbia Law Review 1162, 1176; quoted in Adelman and Deitrich, ibid, 249.

105 Brown, fn. 70 above, 180-191, see also 173-174.

106 Jacobson and Hough, fn. 71 above, 48.

${ }^{107}$ Ulmer and Johnson, fn. 17 above, 284.

${ }^{108}$ Fitzmaurice and Pease, fn. 35 above, 113. 
encourages judges not to think too hard about what the imposition of the sentence really means for the offender's future life and wellbeing, how much greater is this de-sensitisation effect likely to be if the sentence does not even, in the experienced reality of the sentencer, result from her (albeit conventional, familiar, in this way comforting) choice but from a mere discovery that this is the sentence prescribed in a grid for which the sentencer does not have to take any responsibility?

We can get some sense of this by considering the moral and social evil that judging under the federal sentencing guidelines has brought over the criminal justice system in the United States. ${ }^{109}$ These guidelines (which were treated as mandatory until $2005^{110}$ ) were the perfect example of a sentencing framework that replaced sentencing as a directly value-oriented decision with a formalistic approach. Instead of focusing on the person before them, judges focused on various "factual triggers" represented in the sentencing grid. That grid would with near mathematical precision generate the sentence. Having identified it, they no longer needed to think about what it meant in human terms for the offender to undergo this sentence. A judge in a large southern district admitted to Ulmer and Johnson: "I think eventually for many judges the guidelines provide some insulation from kind of the raw human pain that is involved in sentencing somebody." 111 Once insulated from that, it became possible for judges to "hide behind the guidelines" and (in the striking description of one chief federal defender) "do mass sentencings, 20 or 30 hearings a day, and just read out centuries of time."112

The reason why these judges lost any sense of the moral seriousness of what they were doing was that they no longer needed to take moral responsibility for the sentencing decisions they made. In the words of the judge quoted above describing pre-guidelines sentencing as "a tremendous moral burden", the guidelines "absolved you, basically, of the moral responsibility, to some extent, of whether the sentence was too harsh, whether you should have considered some of

109 Taking stock of the extent of that evil is beyond this article. For one judge speaking out, see "The judge who says he's part of the gravest injustice in America", press report available at: http://edition.cnn.com/2017/06/02/politics/mandatoryminimum-sentencing-sessions/index.html.

${ }^{110}$ In 2005, the ruling of the U.S. Supreme Court in United States v. Booker, 543 U.S. 220 made the guidelines effectively advisory.

${ }^{111}$ Ulmer and Johnson, fn. 17 above, 284.

${ }^{112}$ Ulmer and Johnson, ibid, 285. 
these other factors, yadda, yadda, yadda."113 This view was echoed by another of Ulmer and Johnson's interviewees, a U.S. Attorney who remarked that:

You talk to judges over drinks and some tell you that their brothers and sisters for the most part love [the guidelines] ... They love the fact that they don't have to make these hard calls. But then there are some that realize that, "Jesus, this is my job". ${ }^{114}$

The same respondent then added: "I am sure it is those guys that are doing the departures."115

The important point here is that the presence of substantial sentencing discretion is linked to a more acute sense of moral responsibility for the sentencing outcome by the sentencer. One of Brown's interviewees captures this precisely when he stresses (against a sentencing system where you "more or less get a telephone book of instructions that tell you how to sentence and it becomes a matter of looking it up") that "There must always be room to say that fairness and justice does not require this to be done or that fairness and justice does require this to be done." 116 It is only against the backdrop of this possibility and obligation that a judge can, and has to, take substantive (moral) responsibility for the judgment she imposes. It is therefore only against this backdrop that imposing sentence carries with it the weight and personal responsibility of a moral choice, subject to full-fledged moral evaluation by the judge herself and by others. Hence it is only against this backdrop that the seriousness of what they do fully registers with judges. It is thus, to my mind, only against this backdrop that judges can be expected to be fair, to do justice. Formal responsibility that comes with exercising the authority of the law in a particular institutional function is not enough.

This reason for substantial sentencing discretion exists in every case that comes before a judge. A sentencer who merely "executes the law's commands", is a mere messenger or conduit, doesn't speak from a position where she is expected to take responsibility for the judgment she passes as a choice she has made for reasons she can give, and stand behind. Most sentencers shy away from doing very bad things to other people if they cannot shove the responsibility for

\footnotetext{
${ }^{113}$ Ulmer and Johnson, ibid, 284.

${ }^{114}$ Ulmer and Johnson, ibid.

${ }^{115}$ Ulmer and Johnson, ibid.

${ }^{116}$ Brown, fn. 70 above, 171.
} 
this elsewhere. It is precisely this moral burden that provides the best protection against excessive punishment, and the best assurance that the punishments imposed are constructive, moderate and humane.

\subsection{Sentencing and Respect}

One of the judges interviewed by Hough et al. remarked that the very act of sentencing is "a peculiarly naked and direct form of exercising power over somebody". ${ }^{117}$ How can that "naked exercise of power" be reconciled with treating the person over whom it is exercised with respect? Answering this question will help us perceive another important reason in support of substantial sentencing discretion.

In his critical discussion of the effects that mandatory sentencing legislation had on young black and Hispanic offenders in the United States, Pillsbury observed:

\footnotetext{
Because these [extremely severe] penalties [for young offenders charged with murder arising out of gang criminality] are largely mandatory upon conviction, when it comes time for sentencing these young people rarely get seen for who they are, and certainly not for who they could be. ${ }^{118}$
}

When the law insists that punishment, in some of the most severe cases, must be "rendered impersonally" [in the sense that a sentence mandated by law must be imposed], then this "den[ies] the convicted a meaningful opportunity to be seen and heard as a unique person." "119 Obviously, the worry would be less if the punishment was a small fine, the judicial equivalent of a slap on the wrist (say, a speeding ticket). The reason why, for Pillsbury, it becomes offensive and unbearable that the sentence is mechanically decided upon merely on the basis of "offence classification" is that the imposition of this kind of sentence will deform the life of the person who serves it beyond recognition - and that can only be done to someone whose subjectivity we do not respect, engage with, or value. As Pillsbury captures the attitude: "They are their legal record". ${ }^{20}$

Once we see this, the argument for flexibility on the part of the sentencing judge becomes grounded in more than the need to avoid a disproportionately severe sentence. It is so that the judge can take a

${ }^{117}$ Hough, Jacobson and Millie, fn. 78 above, 35.

${ }^{118}$ S H Pillsbury, "Questioning Retribution, Valuing Humility", (2014) 11 Ohio State Journal of Criminal Law 263, 278.

119 Pillsbury, ibid, 277.

${ }^{120}$ Pillsbury, ibid, 278. 
certain position towards an offender - the position that his future matters. And why should a judge be able to take that position, why should he even be expected to? That was again captured well by one of Brown's interviewees:

When I was being trained as a prosecutor, one of the first things my boss said to me was: "It's prosecution in the public interest." It's the same with sentencing. It's sentencing in the public interest. Never forget that the accused is a member of the public. So you cannot possibly, in my view, either prosecute or sentence without considering the individual who has committed the crime. ${ }^{121}$

Sentencers and prosecutors must treat those they are dealing with as co-citizens. They must also treat them with respect for them as persons - as human beings understood in their individuality as a "locus of value". ${ }^{122}$ Ultimately this is a matter of constitutional principle, a principle well captured by Laws LJ when he remarks:

Rule-book justice is barbarous. It treats the criminal not as an individual, but as a member of a class, to be dealt with according to the rules set to govern that class. If the State systematically looks at its citizens, even the most flawed among them, in that grim light, then it looks at them as things not people. ${ }^{123}$

Sentencing discretion is a precondition for the judge to be in a position to give an explanation of the sentence that is not merely an exercise in "buck-passing" ("I am sentencing you to 5 years because your case falls into field A5 of the sentencing grid. Don't ask me to justify this further; I didn't make the grid."). This, in turn, is a precondition for the very possibility of the trial court's sentence to be experienced and accepted by defendants as a response to their crime that treats them as human beings. It is the duality of the sentencing decision as a decision authorised, constrained and guided by law, and made by a person who can hear and respond to the defendant's pleas, that makes it possible to say that the defendant is treated with respect.

${ }^{121}$ Brown, fn. 70 above, 97.

${ }^{122}$ See D Wiggins, "The person as object of science, as subject of experience, and as locus of value" in A R Peacocke and G R Gillett (eds), Persons and Personality, Blackwell 1987.

${ }^{123}$ J Laws, "The Future of Sentencing: A Perspective from the Judiciary", in P Sedgwick (ed), Rethinking Sentencing - A Contribution to the Debate, London: Church House Publishing, 2004, 67. 


\subsection{Responding to Potential Objections}

Ashworth is rightly critical of theories that allow judges to choose between different legitimate aims of sentencing. His objection is predominantly constitutional: "Freedom to select from among the various rationales [of sentencing] is a freedom to determine policy, not a freedom to respond to unusual combinations of facts." ${ }^{124} \mathrm{He}$ also identifies a risk that judges could engage in what he denounces as "pick and mix" sentencing, ${ }^{125}$ at grave cost to predictability and consistency of sentencing outcomes. The latter worry is shared by Cole and Manson who point out that "the blending of penal objectives [in] the sentencing process ... generates its own inevitable tensions due to the inherently contradictory nature of some of the objectives [and can hide] the uncomfortable observation that precision and consistency may be unattainable goals." 126

The concern that judges invested with substantial sentencing discretion would determine policy can be lessened if one recalls that the sentencing decision is about setting reasonable terms for the polity's continued relationship with the offender in view of his crime. This overall objective does not invite or indeed permit judges to base their decisions on a "personal policy preference" for this or that sentencing aim. Any choice of a particular sentencing goal over another would have to be contextually connected to determining the appropriate response to a particular case and a particular offender. As one of the judges interviewed by Davies et al. in their study of sentencing burglars explained,

Depending on the facts, your objectives may change. Potentially there is a range of objectives one may have. You might have protection of the public, particularly for night time burglaries, which is why people would think a substantial sentence would be appropriate ... At the lower end of the scale ... something constructive could be done to help prevent a particular offender from offending again. So one can't say what one's sentencing objectives are specifically until one knows more about the case. ${ }^{127}$

${ }^{124}$ A Ashworth, Sentencing and Criminal Justice, $5^{\text {th }}$ edn, Cambridge: Cambridge University Press, 2012, 76.

125 Ashworth, ibid, 77.

${ }^{126}$ D Cole and A Manson, Release from Imprisonment: The Law of Sentencing, Parole and Judicial Review, Toronto: Carswell, 1990, 16.

${ }^{127}$ M Davies, J-P Takala and J Tyrer, "Sentencing Burglars and Explaining the Differences Between Jurisdictions", (2004) 44 British Journal of Criminology 741, 753. 
But this quotation also speaks to Ashworth's second worry: it (obliquely) mentions general deterrence, specific deterrence/incapacitation (protection of the public) and rehabilitation as possible sentencing goals and thereby implies that a straightforward choice should be made between them. This suggests that there may be a danger that judges will indeed exercise substantial sentencing discretion by "picking and mixing" sentencing goals. This could lead to sentencing outcomes running the whole gamut of extremely harsh sentences imposed on A for goal 1, and B for goal 2, to mild disposals on $\mathrm{C}$ for goal 3 and $\mathrm{D}$ for goal 4 , even when in each of these cases any of the other goals could also plausibly have been made the lodestar of the apportionment of punishment. If this were to result from substantial sentencing discretion, then this would not only make sentencing outcomes unpredictable but hardly prime the system in the direction of moderate sentences.

The response to this worry requires some clarification of the relationship between substantial sentencing discretion and sentencing goals. The point of substantial sentencing discretion is to allow for properly individualised sentencing that responds not just to the offence but also to the offender, the court being expected to impose the most constructive punishment possible in the circumstances. A constructive sentence is aimed at creating the conditions under which full equality and full community with the perpetrator can be re-established. It requires that sentencers remain alert to the specific matrix of concerns raised by the case before them and avoid following a fixed policy of any sort. Take, as an unfortunate example where this was not insisted upon, the Court of Appeal's decision in R. v. Blackshaw. ${ }^{128}$ Here, the Court of Appeal approved of a number of sentences of immediate imprisonment for non-negligible periods of time that had been imposed on individuals who had committed property crimes that were "intrinsic" to the rioting and looting that took place in various cities in England over four days in August 2011, no matter how minor and spontaneous an offender's actions had been. In the sentences under appeal, the trial courts had indicated that immediate custodial sentences had been warranted to (as one of the trial judges had put it) "demonstrate that this conduct would not be tolerated". Assuming that the trial courts had treated this objective as in principle ruling out a non-custodial sentence, then one obvious problem with this approach is how this objective was considered at sentencing: not as a consideration to be given the appropriate degree of weight in

${ }^{128}$ R. v. Blackshaw [2011] EWCA Crim 2312, [2012] 1 W.L.R. 1126. 
the context of every individual case, but by attaching to it a fixed weight that preordained sentence type.

More generally, substantial sentencing discretion must be exercised by performing the sort of bifocal proportionality assessment that I have argued for in a recent publication: a proportionality assessment that strives to arrive at a sanction which stands in an adequate relation both to the seriousness of the offence and to the person and situation of the offender. ${ }^{129}$ This approach to sentencing combines proportionate sentencing principles with the kind of person-responsive sentencing achieved through proper individualisation of sentences. It would rule out raising an individual's sentence based on broad-brush considerations of the kind that "the policy of the law must be X, from which Y must inexorably follow, no matter what". Qua "policy of the law", a sentencing goal must be factored into the system at the general, legislative level and is not appropriately pursued at the expense of individual offenders at sentencing. ${ }^{130}$ Substantial sentencing discretion is not a licence to choose between and pursue policy goals in an impersonal manner; it is about creating the space for a nuanced decision that sets reasonable terms, on behalf of the polity, for continued coexistence with the offender in respect of his crime. In the main, this calls on judges to consider personal factors in sentencing with a view to mitigating the severity of the punishment and where possible give it some constructive form. We should tread very carefully before we also instruct judges to look out for a personal factor that should actively signal to them that the punishment should go up (rather than by its absence suggesting that the punishment should not go down). That risk exists when judges are instructed to increase punishments on grounds of a defendant's supposed dangerousness. How to control against that risk must be the subject of

${ }^{129}$ A du Bois-Pedain, "Punishment as an Inclusionary Practice: Sentencing in a Liberal Constitutional State" in A du Bois-Pedain, M Ulväng and P Asp (eds), Criminal Law and the Authority of the State, Oxford: Hart/Bloomsbury, 2017, 199, 215-224.

${ }^{130}$ In their comparative study of sentencing burglary cases, Davies et al. found that Finnish judges appeared more reluctant to engage in balancing different sentencing goals than their English counterparts, observing that the Finnish judges "seemed to rely on the idea that the criminal justice system as a whole would work towards balanced goals" and, in particular, that "many of them emphasized the goal of general prevention not as something that should drive individual sentencing decisions but as something that the whole criminal justice system would help promote" (fn. 127 above, 764). This captures well the attitude of sentencers that I argue for in the text. 
another publication. All that can be observed here is that much can be said for simply excluding this sort of consideration in most cases. Germany, which uses a two-track system, has a few hundred convicts in "continuing detention" based on their dangerousness ${ }^{131}$ whereas England and Wales stacked up thousands in a flash after introducing a formulaic legal dangerousness indicator, ${ }^{132}$ and even when the imposition of this type of sentence had become discretionary rather than mandatory the courts used it extensively. ${ }^{133}$

\section{CONCLUSION}

In the deeper and dustier recesses of a criminology library, I once stumbled across a book of courtroom anecdotes which, in the present context, is only notable for its title: "Nehmen Sie das Urteil an? Menschen vor dem Richter". ${ }^{34}$ "Do you accept the court's judgment?" is indeed the question German judges traditionally ask the accused after pronouncing the sentence in court. Judges ask it in part for a procedural reason: if the accused plans to appeal his conviction or sentence, the judge may not abbreviate the written reasons for his judgment. But the question also encapsulates something about the special, interactive character of the criminal court's sentencing occasion. It is odd to think of this question being asked in civil cases

${ }^{131}$ Germany, a country with a significantly larger population than England and Wales, kept 524 prisoners in continuing detention on ground of dangerousness in 2016. For the preceding 13 years, the total was below that figure except in 2010, when it also reached 524. Figures available at: https://de.statista.com/statistik/daten/ studie/75094/umfrage/strafgefangene-in-sicherungsverwahrung/.

${ }^{132}$ Indeterminate sentences of imprisonment for public protection (IPP) were introduced as mandatory sentences for certain kinds of recidivist offenders in section 225 of the Criminal Justice Act 2003. In 2008 the wording was amended to state that a court "may" impose an IPP if (also slightly amended) stipulated conditions were met. The numbers of prisoners serving IPP sentences reached 4,461 in June 2008 and peaked at 6,080 in June 2012 (Pat Strickland, Sentences of Imprisonment for Public Protection, London: House of Commons Library, Parliamentary Briefing Paper Number 06086, 9 December 2016, 6). In 2012 IPP sentences were finally abolished, but in the same breath the possibility of a dangerousness-based sentence extension for up to 10 years, again for certain classes recidivist offenders, was introduced (section 226A of the Criminal Justice Act 2003, as amended).

133 J Jacobson and M Hough, Unjust Deserts: Imprisonment for Public Protection, London: Prison Reform Trust, 2010, 8 (pointing out that there was "continuing steady usage of the IPP sentence by the courts").

134 "Do you accept the court's judgment? People before the judge". 
(where the court's judgment is merely "announced", often quite some time after any court hearing, and usually to an empty room). And this has to do with what the subtitle of this otherwise unremarkable collection of stories also captures: that, here, one human being stands before another human being, the latter invested with authority and thus in a position of power over the other. No matter that the source of the authority is public and collective: it is still not the abstract collectivity but another human individual who speaks. Lord Judge, who ended his judicial career as Lord Chief Justice, was surely right when he said that:

sentencing a fellow human being is ... a human skill, a skill in humanity, and ... it is this skill, and its application, that is embodied in the possibly pompous sounding phrase, "judicial discretion". ${ }^{135}$

To exercise that human skill, judges need substantial sentencing discretion. A judge must be able to engage directly in a nuanced manner with the moral issues raised by a case, and - just as importantly - with the people before him. That such an engagement happens within the broad framework set by law, and in exercise of an authority conferred by the polity in the public interest, is understood as placing on the judge an obligation to consider what terms the polity ought reasonably to set for its continued interactions with the offender in view of his crime. The seriousness of a particular violation of the law must be gauged concretely and not in the abstract, and the same is true for the appropriateness of the sanctioning response. A way forward must be found, and charted. It is true that the judgment must also mark the seriousness of what happened - if it was indeed serious - but this, too, cannot be done in a schematic or formulaic way. To help offenders turn their lives around isn't, nor can it be, the only consideration that shapes the punishment, but it is rightly one which can become determinative of the type and severity of punishment imposed in particular cases. This is an important upshot of a criminal justice system that expects judges to set reasonable terms of future coexistence with an offender on behalf of the polity.

Sufficient dispositional flexibility on the part of sentencing judges to allow them to impose the most appropriate sentence in the circumstances is not only a functional necessity in any system that offers a range of dispositional options with a view to enabling constructive

${ }^{135}$ I Judge, "Current Sentencing Issues", Address delivered at Lincoln’s Inn, 29 October 2007, London. 
punishments to be imposed. This kind of system also gives effect to the constitutional commitment to only proportionate curtailment of each other's rights that binds the polity also in its responses to those convicted of criminal offences. The political-constitutional case for substantial sentencing discretion further builds on the relations of respect that can only be manifested when the judge is expected to, and in a position to, take responsibility for the punishment imposed. A power to reshape an individual's relationship with the rest of us in response to a crime she has committed can only be exercised justifiably if the power-holder is prepared to engage with the offender as a human person. This is at the heart of a constitutional case for individualised (or person-responsive) sentencing.

It might be objected that the view defended here only fits sentencing systems which accept that criminal punishment is about setting appropriate terms for the future interaction between the offender and the polity in view of the offender's crime, and that it therefore holds no relevance for systems where the task of the trial court is not conceptualised in this way (but rather, say, as imposing deserved retribution or as deterring crime). To object thus would be to misunderstand the position advanced here. What underlies it is a twofold conviction: First, that in every legal system, no matter what penal philosophy is taken to underpin their sentencing practices, the sentencing judgment must and will serve this term-setting function. Second, that in all legal systems which recognise people as holders of fundamental rights, are committed to treating them with respect for their dignity and personhood, and expect their public institutions to serve the interests of all (in other words, systems which have made the familiar constitutional commitments of liberal-democratic states), only a sentencing framework that calls for individualisation of sentences can be justified as leading to appropriate and non-arbitrary exercises of state power.

Note that this is not an argument for unfettered or unaccountable sentencing discretion. Any sentencing system, however one designs it, exposes individuals to the dangers of power being exercised ineptly or maliciously. While I have made a case here that substantial sentencing discretion should be a feature of our sentencing system, it is a feature that must be embedded in a broader setting of appropriately designed institutional safeguards. 


\section{OPEN ACCESS}

This article is distributed under the terms of the Creative Commons Attribution 4.0 International License (http://creativecommons.org/ licenses/by $/ 4.0 /$ ), which permits unrestricted use, distribution, and reproduction in any medium, provided you give appropriate credit to the original author(s) and the source, provide a link to the Creative Commons license, and indicate if changes were made. 